\title{
The Effect of Entrepreneurial Marketing on Outcome Goals in SMEs
}

\author{
Richard C. Becherer \\ Marilyn M. Helms \\ John P. McDonald
}

\begin{abstract}
7 bis study examines bow entrepreneurial marketing dimensions (proactiveness, opportunity focused, leveraging, innovativeness, risk taking, value creation, and customer intensity) are related to qualitative and quantitative outcome measures for the SME and the entrepreneur (including company success, customer success, financial success, satisfaction with return goals, satisfaction with growth goals, excellence, and the entrepreneur's standard of living). Using factor analysis, three success outcome variables (financial, customer, and strong company success) emerged together. A separate factor analysis identified satisfactory growth and return goals. Stepwise regression revealed entrepreneurial marketing impacts outcome variables, particularly value creation. Implications for entrepreneurs and areas for research are included.
\end{abstract}

Keywords: entrepreneurial marketing; entrepreneur; value creation; opportunity; leveraging; excellence

While marketing plays a significant role in successful organizations, it can be argued that marketing is even more critical for small to mid-sized enterprises (SMEs), for which the loss or gain of a single customer can often determine firm survival. What has become increasingly apparent to researchers is that conventional marketing practices are not always available or appropriate for entrepreneurial firms. The very fact of its newness means a nascent business venture is more likely to face both uncertain market conditions and limited resources for marketing. When pursuing new opportunities with limited resources, the entrepreneur must use innovative approaches in the face of such constraints. While the marketing approaches used by entrepreneurs reflect this innovative orientation, they may vary in their relationship or effect on outcome goals. It is critical for a new venture to understand which entrepreneurial marketing practices are most effective and therefore important to achieve a variety of successful outcome goals and ultimately for profitability and growth. Therefore, the purpose of this article is to link entrepreneurial marketing practices with outcome goals in SMEs.

\section{Entrepreneurial Marketing}

The term "entrepreneurial marketing" merges two formerly distinct disciplines and is used to describe the marketing processes of firms pursuing opportunities in uncertain market circumstances often under constrained resource conditions (Collinson \& Shaw, 2001; Hills, 1987; Omura, Calantone, \& Schmidt, 1993). Entrepreneurial marketing utilizes a "big picture" perspective and focuses on creative approaches to innovation, risk management, resource leveraging, and value creation. The term describes a range of actions and responses SMEs can employ (Becherer, Haynes, and Helms, 2008). Read, Dew, Sarasvathy, Song, and Wilbank (2009) compared the marketing approach of entrepreneurs versus managers with little entrepreneurial expertise and confirmed significant differences exist when marketing under uncertainty. They found managers without entrepreneurial expertise relied on predictive marketing techniques while the entrepreneurs marketing tactics used effectual or nonpredictive logic.

Beverland and Lockshin (2004) defined entrepreneurial marketing as "effectual action" or the adaptation of marketing theory for the unique needs of small businesses. These effectual actions simultaneously address many issues: opportunity, innovation, risk, and resource constraints. For the SME, these actions are the task of the individual owner/operator. Constant attention to marketing is critical to success for newly launched or growing ventures (Hisrich, 1992; Becherer, Halstead \& Haynes, 2003; Becherer, Haynes, \& Fletcher, 2006). Simultaneously these decisions also pose some of the greatest challenges to these ventures (Morris, Schindehutte, \& LaForge, 2002; Sarasvathy, 2001; Kirzner, 1997; Stokes, 2000; Carson 2001).

Because SMEs face specific constraints, they are set apart from their larger business counterparts that have more longevity. Thus there is justification for the adoption of an entrepreneurial marketing philosophy (Birley, 1989, 1982), particularly in highly innovative organizations (Chaston \& Mangles, 1999). Gruber (2004) agreed marketing is a major determinant of success in all new firms. Marketing also is rated extremely important by venture capitalists and Chaston (1997) found entrepreneurial marketing is more appropriate in smaller firms.

Entrepreneurial marketing has been suggested as most effective when environmental change is great and resources are limited (Becherer \& Maurer, 1997). Martin's (2009) research also found distinctions. She compared traditional 
corporate marketing to entrepreneurial marketing and validated a framework for analysis of marketing practices specific to entrepreneurs, highlighting the differences in marketing practices by entrepreneurs.

Traditional marketing strategies, emphasizing effectiveness (market penetration) and efficiency, tend to dominate when markets become more stable and firms become more established (Morris, Schindehutte, \& LaForge 2002). In contrast, a firm's emphasis on entrepreneurial marketing varies in intensity based on the stage of organizational development and level of environmental turbulence or hostility. Firms striking out in new directions will tend to have a greater emphasis on the entrepreneurial marketing dimensions.

Morris, Schindehutte, and LaForge (2002) characterize entrepreneurial marketing as an organizational orientation having seven underlying dimensions. Four of these dimensions-proactiveness, opportunity-focused, risk taking, and innovation-oriented-build directly on research examining the entrepreneurial orientation of the firm. Together with customer intensity, resource leveraging, and value creation, each dimension can be employed to a greater or lesser extent by an SME. Each of these seven dimensions is discussed below.

\section{Dimensions of Entrepreneurial Marketing}

Proactiveness. Proactiveness has been characterized as taking action to influence a firm's environment (Bateman \& Crant, 1993). Involving two related marketing actions, organizational proactiveness consists first of practices by which the firm anticipates challenging situations and second, of the actions taken to manage those events. From an entrepreneurial perspective, proactivity describes marketing actions through which the firm redefines its external conditions to reduce uncertainty and lessen dependency and vulnerability.

Opportunity-Focused. Recognition and pursuit of opportunity are marketing actions critical to SME success. Market potential is evaluated by the degree of fit relative to the capabilities and resources of the firm. It is the ability of the firm to select the "right" opportunity that determines success (Hamel \& Prahalad, 1994; Hamel, 2000).

Matsuno, Metzer and Özsomer (2002) suggested an organization's market knowledge determines whether innovation is implemented at the appropriate time. Under less ideal circumstances, market knowledge serves as a constraint, preventing the firm from squandering resources in vain. Market knowledge allows firms to take the right action at the right time, directing the organization toward success. Opportunities requiring substantial resource commitments may be unattainable to smaller owner-operated firms. However, in the SME, the recognition and pursuit of opportunity are more closely aligned with the entrepreneur's individual perceptions (Schindehutte \& Morris, 2001; Forlani \& Mullins, 2000;
Mullins \& Forlani, 2005). Where others perceive problems, entrepreneurs are more likely to see potential (Palich \& Bagby, 1995).

Risk Taking. Early studies of risk taking centered on the premise that entrepreneurs are predisposed to take on risky ventures (d'Ambroise \& Muldowney, 1988). As opportunities represent possible gains, pursuit of that gain must be tempered by the potential of loss through miscalculated efforts. Within an entrepreneurial framework, risk taking is not only the willingness to take a chance on an opportunity, it is the ability of the organization to use calculated actions to mitigate the risk inherent in opportunity pursuit. Owner-operator risk-taking attitudes play a crucial role in determining the actions a firm undertakes, with entrepreneurs viewing risk taking as simply part of their job (Mullins \& Forlani, 2005). Dushnitsky (2010) characterized entrepreneurs as optimistic individuals who consciously pursue their goals. He agreed too that these goals may often be self-serving.

While a firm's bold market-breaking actions might be viewed as high risk, entrepreneurs view those actions as well within their capabilities and perceive less risk than others. Rather than having a higher propensity for undertaking risky ventures, entrepreneurs instead have a lower level of risk perception (Palich \& Bagby, 1995). In a differing approach to risk taking, an SME might choose a more incremental process and take actions to pursue a series of smaller, less risky outcomes (Venkatraman, 1989; Dickson \& Giglierano, 1986). In their 2010 study of entrepreneurial persistence, Gompers, Kovner, Lerner, and Scharfstein found entrepreneurs with a record of past success are tenacious in selecting the right industry and the right time to start new ventures. They agree entrepreneurs who demonstrate market timing skills are more likely to outperform industry peers.

Innovation-Oriented. Innovation-oriented marketing actions allow the firm to concentrate on ideas that lead to new markets, products or processes. The degree to which a successful organization emphasizes innovation in its marketing actions can range from the highly innovative new market creator to the incremental market builder.The market creator must break with past solutions to offer the customer a radically different value while the incremental innovator builds on existing customer relations and market knowledge. SMEs may choose to focus on innovative means of marketing since the firm may not have the resources to meet or maintain industry standards (Carson \& Gilmore, 2000).

Marcati, Guido, and Peluso (2008) found entrepreneurs display a general innovativeness or openness to newness and they also display a specific predisposition to be among the first to adopt innovation within a specific domain. In a study comparing traditional, corporate marketing to entrepreneurial marketing, Martin (2009) found, in the case of the entrepreneur, the marketing strategy supersedes tradi- 
tional marketing theory by the creativity, flexibility, and innovation exhibited by the day-to-day entrepreneurs. In their model of entrepreneurship as a solution to environmental issues, York and Venkataraman (2010) found entrepreneurs are better at addressing environmental uncertainty and providing innovation.

Customer Intensity. Many studies suggested successful organizations are those that place a greater emphasis on customer intensity (Sheth, Sisodia \& Sharma 2000; Han, Kim, \& Srivastava 1998; Hamel \& Prahalad 1994; Jaworski \& Kohli 1993; Narver \& Slater 1990). Spence and Essoussi (2010) confirmed that entrepreneurs need to be aware that their public image may reflect consumers' perceptions of their firm. However, it has also been suggested that extreme customer orientations might inhibit the breakthrough innovations that create markets and disrupt equilibrium, since these radical changes are out in front of customers (Deshpande, Farley \& Webster, 1993). The dimension of customer intensity builds on what is often viewed as a central driving force of marketing in the organization-a "customer-centric" orientation employing innovative approaches to create, build, and sustain customer relationships.

Resource Leveraging. The dimension of resource leveraging is not simply a matter of effectively using limited resources, but instead a creative synergistic process. In some cases it is recognizing a resource not seen by others (Morris, Schindehutte, \& LaForge, 2002). In SMEs, instead of being constrained by resource limitations, the firm devises an innovative marketing strategy and is thus able to access resources so more can be done with less, often mitigating risk through a greater use of leveraging. Schindehutte and Morris (2001) found successful SMEs were more likely to employ resource leveraging practices such as resource sharing and outsourcing of key functions. Studies found that access to resources increases innovation and risk taking while resource constraints stifle entrepreneurial efforts (Hamel 2000; Prahalad \& Hamel, 1990). Conversely, studies have found resource constraints led to greater entrepreneurial efforts, suggesting the entrepreneur's perception may be more important than the resource availability (Wiklund \& Shepherd 2005; Schindehutte \& Morris 2001).

Value Creation. Value creation, central in the definition of entrepreneurial activity, is also integral to the marketing orientation of a firm (Jaworski \& Kohli, 1993; Slater \& Narver 1995; Han, Kim, \& Srivastava 1998). While value creation is an essential condition for exchange to occur, successful firms emphasize the value creation activities best suited to their strategic intent within their competitive niche (Miller \& Floricel, 2004). While traditional marketing has placed more focus on the transaction and customer relationship, the focal point of entrepreneurial marketing is innovative and is oriented toward value creation (Morris, Schindehutte, \&
LaForge, 2002). Entrepreneurs achieve better results when they find new ways to create or discover value (Becherer, Finch, \& Helms, 2005/6). According to Li, Huang, and Tsai (2009) entrepreneurial orientation is positively related to firm performance. They further assert the knowledge creation process plays a mediating role in the relationship.

\section{Entrepreneurial Outcomes}

Outcomes for SMEs can be measured in a number of quantitative ways and unlike large enterprises and corporations, the outcomes important for the entrepreneur are often qualitative. Even though traditional profit-motive outcomes are valid for entrepreneurs, there are a host of other reasons for starting a business that include being their own boss, pursuing their own ideas, and pursuing opportunities without regard to their current resources (Barringer \& Ireland, 2010). The entrepreneur is interested in financially oriented goals of sales growth and increased market share and overall return on their investment for their willingness to assume risks. Additionally, entrepreneurs and owner/operators also measure their success in ways other than pure goal achievement. They can focus on building a company that attains success in many ways, such as a solid customer base or a strong company that can sustain itself and company employees for many years. There are also many criteria and standards to evaluate overall company excellence as an outcome. This notion of building an organization that would be respected for its general excellence is an important outcome for some company owner/operators. Lastly, personal outcomes that directly affect the owner/operator in terms of income, status, or an improved standard of living are also important to consider as the outcomes of the company directly impact the personal outcomes for the owner/operator or entrepreneur.

\section{Linking Entrepreneurial Marketing Dimensions and Outcomes}

The premise of this research is that entrepreneurial marketing is critical to the success of the SME. This investigation examines how marketing dimensions can be linked to the various business outcomes. Hence the following hypotheses emerge.

\section{Hypotbeses}

There are a number of ways to measure goal achievement of the firm. One measure is how well a business performs in terms of goals related to growth in sales revenue, profit, or market share, as well as financial returns, goals relative to capital investment, or equity. Thus the first two hypotheses are

H1: Entrepreneurial marketing dimensions have a positive effect on satisfying growth goals. 


\section{H2: Entrepreneurial marketing dimensions have a positive effect on satisfying return goals.}

At start-up, most entrepreneurs have a vision of the firm they aspire to own and the various dimensions of potential success that can be achieved. Generally, many entrepreneurial firms are created to generate financial success, but often the entrepreneur secures equal or even more satisfaction from initiating a company that creates a loyal customer following or a company with a solid employee base and a good reputation. Therefore to assess success outcomes, three different hypotheses are required.

\section{H3: Entrepreneurial marketing dimensions have a} positive effect on customer success.

H4: Entrepreneurial marketing dimensions have a positive effect on financial success.

H5: Entrepreneurial marketing dimensions have a positive effect on strong company success.

Entrepreneurial owner/managers of SMEs also have personal outcome goals both for high achievement in their company and for their own personal standard of living. The longrun viability of a firm is based on how well it creates management practices and controls that result in an "excellent" overall organization with an ability to achieve sustained performance. The success of an entrepreneur or owner/ manager is often judged by how the compensation from the venture impacts their personal wealth and standard of living. Thus the final two hypotheses are

H6: Entrepreneurial marketing dimensions have a positive effect on overall company excellence. H7: Entrepreneurial marketing dimensions have a positive effect on the owner/operator's personal standard of living.

\section{Methodology The Sample}

Using a national mailing list, a stratified random sample was created of 1,800 owner/operators of small to medium sized businesses (SMEs). The sample included equal numbers of manufacturing businesses, wholesale/distributors, retail businesses, and service businesses. The sample mailing included a cover letter explaining the nature of the study and its anonymity, the questionnaire, and a postage-paid return envelope. Three weeks later a second complete mailing was sent to the entire sample encouraging completion of the survey if they had not already done so.

Completed questionnaires were received from 174 respondents for a response rate of 9.7 percent, which is typical for mail surveys. The first $25(n=35)$ of the 174 respons- es were compared with the last 20 percent $(n=35)$ on all key variables and no significant differences in response patterns were identified. This would indicate that nonresponse bias was not a problem (see Armstrong \& Overton, 1977). Table 1 provides the demographics of the sample.

As indicated in the respondent profile in Table 1, the respondents were quite diverse. Manufacturing businesses made up 5.7 percent of the sample while retail businesses constituted 18.4 percent of the sample. Nearly half (47.1\%) the businesses operated for 11 years or more and $10.3 \%$ percent had 31 or more employees. Most were wholesale and distribution businesses (52.9\%) and local in scope (47.1\%), although international $(8.0 \%)$ and nationally-oriented (10.9\%) businesses were represented.

\section{Measures}

Business Success (Customer, Financial and Strong Company) Measure. Positive outcomes for small to midsized enterprises can be evaluated from a number of perspectives on various dimensions. To capture these multiple viewpoints, using a five-point Likert-type scale, respondents were asked to indicate their level of agreement with nine state-

Table 1. Demographics of the Sampled Companies

\begin{tabular}{|l|r|r|}
\hline & Number & Percentage \\
\hline Industry Category & 10 & $5.7 \%$ \\
$\quad$ Manufacturing & 92 & $52.9 \%$ \\
Wholesale/Distribution & 9 & $5.2 \%$ \\
Service & 32 & $18.4 \%$ \\
Retail & 31 & $17.8 \%$ \\
Other & 14 & \\
\hline Scope of Business Operations & 19 & $10.9 \%$ \\
International & 53 & $30.5 \%$ \\
National & 6 & $3.4 \%$ \\
Regional & 82 & $47.1 \%$ \\
State-wide & 26 & $14.9 \%$ \\
Local & 66 & $37.9 \%$ \\
\hline Company Age & 64 & $36.8 \%$ \\
1-3 years & 18 & $10.3 \%$ \\
4-10 years & & \\
11-25 years & & $14.9 \%$ \\
26+ years & 26 & $37.9 \%$ \\
\hline Number of Full-Time & 66 & $36.8 \%$ \\
Employees & 64 & $10.3 \%$ \\
1-2 & 18 & \\
3-10 & 26 & $18.4 \%$ \\
11-30 & & $14.9 \%$ \\
31+ & & $15.5 \%$ \\
\hline Annual Sales & & $10.3 \%$ \\
Under \$100,000 & & \\
100,000 - 249,000 & & \\
250,000 - 999,999 & & \\
1,000,000 to 4,999,999 $5,000,000+$ & & \\
No Response/Refused & & \\
\hline
\end{tabular}


ments representing aspects of business success. Items included "successful in creating a positive reputation," "successful in growing sales," and "successful in positioning the company for long-term prosperity." Using factor analysis, three underlying success dimensions-financial success, customer satisfaction success, and strong company success-emerged from the nine variables. Table 2 shows the factor analysis that created the "success" outcome variables. As the table shows, the factor loadings for Customer Success are market focused and include Create Customer Satisfaction and Create Positive Reputation where the loadings were .918 for each measure. The second factor, Financial Success, had five variables with loadings ranging from .677 up to .835 . The highest loading was for the Profitability measure (.835) closely followed by Income for the Owner (.833), and then Sales Growth (.733), Increase Customer Base, (.698) and finally Position for LongTerm Prosperity ( .677). The final success factor, Strong Company Success is best characterized by Adding Good Employees (.801) and Operates Well with/without Owner (.752).

A Chronbach's Alpha Coefficient was calculated for each of the success measures. Financial Success (.86) and Customer Success (.87) were both very high. Strong Company Success (.54) was lower, but it was still used in this study due to the fact that this research is exploratory.

Table 2. Factor Analysis of Success Outcomes

\begin{tabular}{|c|c|c|c|c|}
\hline & $\begin{array}{c}\text { Aspects of } \\
\text { Business Success }\end{array}$ & $\begin{array}{l}\text { Customer } \\
\text { Success }\end{array}$ & $\begin{array}{l}\text { Financial } \\
\text { Success }\end{array}$ & $\begin{array}{c}\text { Strong } \\
\text { Company } \\
\text { Success }\end{array}$ \\
\hline 1 & $\begin{array}{l}\text { Create Customer } \\
\text { Satisfaction }\end{array}$ & 0.918 & 0.118 & 0.072 \\
\hline 2 & $\begin{array}{l}\text { Create Positive } \\
\text { Reputation }\end{array}$ & 0.918 & 0.184 & 0.071 \\
\hline 3 & Profitability & 0.221 & 0.835 & 0.000 \\
\hline 4 & Sales Growth & 0.126 & 0.733 & 0.335 \\
\hline 5 & Income for Owner & 0.206 & 0.833 & 0.053 \\
\hline 6 & $\begin{array}{c}\text { Increase Customer } \\
\text { Base }\end{array}$ & -0.008 & 0.698 & 0.365 \\
\hline 7 & $\begin{array}{l}\text { Position for Long- } \\
\text { Term Prosperity }\end{array}$ & 0.003 & 0.677 & 0.524 \\
\hline 8 & $\begin{array}{l}\text { Adding Good } \\
\text { Employees }\end{array}$ & 0.157 & 0.150 & 0.801 \\
\hline 9 & $\begin{array}{c}\text { Operates Well } \\
\text { with/without } \\
\text { Owner }\end{array}$ & -0.002 & .0165 & 0.752 \\
\hline
\end{tabular}

Goal Achievement Measures. Additional outcome measures were based on self-reports of how well the company achieved goals. Owner/operators were asked to rate how satisfied they were with their company's achievement of seven specific goals. These seven items were also factor analyzed and two underlying dimensions emerged.The factor matrix is presented in Table 3. Three of the four variables with high loadings on the Satisfaction with Return Goals emphasize returns including Return on Investment (factor loading of .868), Return on Equity (.826), and Return on Assets (.824). The fourth measure is Net Profit Margin (.805). For the second factor, Satisfaction with Growth Goals, the Growth in Number of Employees is the strongest measure (.855 loading) followed by Market Share Growth (.772) and Sales Growth (.559).

Reliability coefficients were calculated for each of the growth outcome measures. The Satisfaction with Return Goals measure with four items was .70, and the Satisfaction with Growth Goals with three items was .89. These values indicated satisfactory reliability.

Overall Excellence Measure. The "excellence" measure is based on a standardized outcome measure, an adaptation of the EXCELL scale (Peters \&Waterman, 1982). The original 16 attributes that characterized excellent companies that achieved a sustainable business were adapted and operationalized by Sharma, Netemeyer and Mahajan (1990) who created an EXCELL scale in only eight dimensions. Our study used the condensed adaptation to accommodate the constraints of the questionnaire and to encourage a higher

Table 3. Factor Analysis of Satisfaction with Goals

\begin{tabular}{|c|c|c|c|}
\hline & & $\begin{array}{c}\text { Satisfaction } \\
\text { with Return } \\
\text { GoalsCustomer } \\
\text { Success }\end{array}$ & $\begin{array}{c}\text { Satisfaction } \\
\text { with Growth } \\
\text { Goals }\end{array}$ \\
\hline 1 & Return on Investment & 0.868 & 0.221 \\
\hline 2 & Return on Equity & 0.826 & 0.304 \\
\hline 3 & Net Profit Margin & 0.805 & 0.132 \\
\hline 4 & Return on Assets & 0.824 & 0.314 \\
\hline 5 & Sales Growth & 0.469 & 0.559 \\
\hline 6 & $\begin{array}{c}\text { Market Share Growth } \\
\text { ( }\end{array}$ & -0.318 & $\mathbf{0 . 7 7 2}$ \\
\hline 7 & $\begin{array}{c}\text { Growth in Number of } \\
\text { Employees }\end{array}$ & 0.088 & 0.855 \\
\hline & Alpha & 0.89 & 0.70 \\
\hline
\end{tabular}


response rate. The "excellence" outcome measure had an alpha reliability of .71 .

Personal Standard of Living Measure. From the perspective of the owner/operator, success of the business is also a function of how the venture personally affects them. To evaluate this dimension, respondent owner/operators were asked how they would describe their standard of living today compared with their standard of living at the time they started their business. Using a five-point Likert-type scale, respondents rated their standard of living from "much worse" (1), through "about the same" (3), to "much improved" (5).

Entrepreneurial Marketing Dimension Measure. Because of the exploratory nature of this research, the items used to measure seven entrepreneurial marketing dimensions were

Table 4. Entrepreneurial Marketing Dimension Measures

Proactiveness (Coefficient Alpha $=$.78)

- I am constantly on the lookout for new ways to improve my company.

- I am always looking for better ways to do things in my company.

- I excel at identifying opportunities for my company.

- I am great at turning problems at my company into opportunities.

- When it comes to my company, I am more action oriented than reaction oriented.

- Nothing is more exciting in my company than seeing my ideas turn into reality.

- In my company, I enjoy facing and overcoming obstacles to my ideas.

Opportunity-Focused (Coefficient Alpha $=.72$ )

- My management approach looks beyond current customers and markets for more opportunities for our company.

- I am good at recognizing and pursing opportunities for my company.

- I would characterize my company as opportunity driven.

- My company is always looking for new opportunities.

- My company will do whatever it takes to pursue a new opportunity.

Risk-Taking Orientation (Coefficient Alpha = .74)

- My business would rather accept a risk to pursue an opportunity than miss it altogether.

- My business is willing to take risks when we think it will benefit the company.

- My company would not be considered gamblers, but we do take risks.

Innovation-Oriented (Coefficient Alpha = .72)

- My company tries to use innovative approaches if it will help them get the job done more efficiently.

- Being innovative is a competitive advantage for my company.

- My company tends to be more innovative that most of my competitors.

- My company's top management creates an atmosphere that encourages creativity and innovativeness.

Customer Intensity (Coefficient Alpha = .77)

- I frequently measure my company's customer satisfaction.

- I expect that all employees in our firm recognize the importance of satisfying our customers.

- My business objectives are driven by customer satisfaction.

- I pay close attention to after-sales service.

- I encourage my employees to strive for innovative approaches to creating relationships with customers.

- I closely monitor and assess my company's level of commitment in serving customers' needs.

- I ensure that business strategies in my company are driven by the goals of increasing customer value.

- Sometimes, my company does not pay attention to customers who think they know more about our business than we do.

- I make sure that my company's competitive advantage is based on understanding customers' needs.

Resource Leveraging (Coefficient Alpha $=.62$ )

- I have used networking and/or an exchange of favors to our advantage in my company.

- I have been able to leverage our resources by bartering or sharing.

- People who know me well would say that I am persistent, even tenacious, in overcoming obstacles.

- I use creative approaches to make things happen.

- My company prides itself on doing more with less.

- In the past, we have always found a way to get the resources we need to get the job done.

- My company has a small staff that delegates authority efficiently.

Value Creation (Coefficient Alpha $=.72$ )

- I make sure that my company creates value for consumers with excellent customer service.

- I make sure that my company does an excellent job of creating value for customers.

- I make sure my company's pricing structure is designed to reflect value created for customers.

- I integrate business functions in my company to better serve the target market needs.

- I make sure my managers understand how employees can contribute to value for customers.

- Providing value for our customers is the most important thing my company does.

- My company's values are the driving force behind its operation. 
drawn both from studies that had previously examined each dimension.Also, a series of statements was created using definitions and discussions of entrepreneurial marketing dimensions. Respondents were asked to rate their agreement on a five-point Likert-type scale with a series of statements regarding the operation of their company. With limited existing research on measures of entrepreneurial marketing dimensions, validity and reliability continue to evolve. The entrepreneurial marketing measures utilized in this study reflect Cronbach's alpha reliability coefficients from 0.55 to 0.70 , acceptable for exploratory research. Intercorrelation analysis refined the scales to the final items presented in Table 4.

\section{Results and Discussion}

To understand the relationship between the seven entrepreneurial marketing dimensions and the outcome variables, a stepwise regression was utilized. Table 5 shows the seven stepwise regression analyses regressing the entrepreneurial marketing dimension variables as independent variables against each of the outcome variables as a dependent variable. The extent to which each entrepreneurial marketing variable impacts on each outcome variable is determined by which entrepreneurial marketing dimensions significantly enter each stepwise regression. Entrepreneurial marketing dimensions that enter the regression contribute to explaining the variance in each of the outcome variables. The entrepreneurial marketing dimensions listed in Table 5 for each stepwise regression are all significant and contribute to explaining each outcome variable.

As is indicated in Table 5, the entrepreneurial marketing dimension that has a significant and positive impact on both Growth Goals and Return Goals is the Value Creation Dimension ( $p \leq 0.00$ for both). This dimension, which reflects the extent to which the SME focuses on providing value for customers is the only one that directly and positively affects achievement of growth and financial return goals. Hence, both $\mathrm{H} 1$ and $\mathrm{H} 2$ are supported, regarding the value-driven entrepreneurial marketing dimension.

Regarding the success related outcome variables (customer success, financial success, and strong company success), value creation ( $\mathrm{p} \leq 0.02)$ is again an entrepreneurial marketing dimension that significantly and positively affects each aspect of success. Relative to the specific success outcome variables, as would be expected, customer intensity ( $\mathrm{p}$ $\leq 0.03$ ) positively and significantly affects the customer-success outcome variable. Regarding financial success as an outcome, in addition to the value creation entrepreneurial marketing dimension ( $\mathrm{p} \leq 0.00)$, risk taking ( $\mathrm{p} \leq 0.00)$ also is positively and significantly related. Relative to "strong company success," innovativeness $(\mathrm{p} \leq 0.01)$ and leveraging $(\mathrm{p} \leq 0.04)$ are the two entrepreneurial marketing dimensions, along with value-creation ( $\mathrm{p} \leq 0.00)$, that have a significant and pos- itive impact on this success outcome. While it is interesting that value-creation impacts all three aspects of success, it is intuitive that risk taking has a positive and significant effect on financial success while customer intensity is directly related to customer success. Relative to building a strong company, among these respondent SME's, it is interesting being innovative and leveraging resources, along with being value creation driven are the variables that have a significant impact on building a strong company. Hence there is support for $\mathrm{H} 3, \mathrm{H} 4$ and $\mathrm{H} 5$ relative to specific entrepreneurial marketing dimensions for each.

Regarding the excellence outcome measure, several entrepreneurial marketing dimensions relate both directly and significantly to this outcome. The four dimensions that demonstrated this relationship are value-creation, $(\mathrm{p} \leq 0.00)$, proactiveness ( $p \leq 0.00)$, innovation-oriented ( $p \leq 0.00)$, and customer intensity $(\mathrm{p} \leq 0.00)$. It is interesting that again the value creation dimension is important. Providing value to customers as a priority is related to creating an excellent company along with being proactive in marketing, seeking opportunities, and being innovative and maintaining a customer focus. Based on the above analysis, H6 is supported with four entrepreneurial marketing dimensions having a positive and significant effect on overall company excellence.

The entrepreneur's personal standard of living is an important outcome and an important reason for becoming an entrepreneur or owner/operator.The entrepreneurial marketing dimension that has a positive and significant effect on the entrepreneur's personal standard of living is their risktaking orientation $(\mathrm{p} \leq 0.01)$. This supports the well-known axiom that entrepreneurs are willing to assume risk in order to achieve a reward. Therefore $\mathrm{H} 7$ is supported, suggesting perhaps that risk taking is a quality that entrepreneurs must possess as compared to managers and other professions.

Of interest is the fact that opportunity focused as an entrepreneurial marketing dimension did not significantly impact any of the outcome measures in the study. So while six of the seven entrepreneurial marketing dimensions directly and positively affected outcome variables in the SMEs included in this research, opportunity focused did not have a similar effect. It may be that other outcome variables such as opening new markets or finding new customer segments would be directly impacted by the opportunity focused dimensions. Similarly, opportunity focused may relate better to SMEs closer to start-up in their life-cycle as compared to more established companies.

It is also of interest that while six of the seven entrepreneurial marketing variables had significant impacts on outcome variables, only the "excellence outcome" with the four independent entrepreneurial marketing dimensions (value creation, proactiveness, innovation-oriented, and customer 
intensity) had a large R2 of 0.66. The R2s for other outcome variable entrepreneurial marketing dimension relationships ranged from 0.04 to 0.25 . The high $\mathrm{R} 2$ for the excellence outcome variable may also reflect that more entrepreneurial marketing outcome variables were significantly related to excellence.Thus additional significant variables in the regression equation may inflate the R2.

\section{Conclusions}

Based on the results of this research, it would appear entrepreneurial marketing dimensions directly and positively influence outcomes related to owner-operated SMEs. The value-creation dimension stands out as an aspect of entrepreneurial marketing that affects not only financial performance but also growth, customer success, and generally building a

\begin{tabular}{|c|c|c|c|}
\hline \multicolumn{4}{|c|}{$\begin{array}{l}\text { Table 5. Stepwise Regression Analyses of Entrepreneurial Marketing } \\
\text { on Outcome Variables }\end{array}$} \\
\hline \multicolumn{4}{|c|}{$\begin{array}{l}\text { Dependent Variable: Satisfied Growth Goals } \\
\qquad \mathrm{R} 2=.07 ; \mathrm{F}=12.09 ; \mathrm{Sig}=.00\end{array}$} \\
\hline $\begin{array}{c}\text { Entrepreneurial Dimension } \\
\text { Entered }\end{array}$ & Beta & $\mathbf{t}$ & Significance \\
\hline Value Creation & 0.271 & 3.48 & 0.00 \\
\hline \multicolumn{4}{|c|}{$\begin{array}{l}\text { Dependent Variable: Satisfied Return Goals } \\
\qquad \mathrm{R} 2=.06 ; \mathrm{F}=10.07 ; \mathrm{Sig}=.00\end{array}$} \\
\hline $\begin{array}{c}\text { Entrepreneurial Dimension } \\
\text { Entered }\end{array}$ & Beta & $\mathbf{t}$ & Significance \\
\hline Value Creation & 0.249 & 3.17 & 0.00 \\
\hline \multicolumn{4}{|c|}{$\begin{array}{l}\text { Dependent Variable: Customer Success } \\
\qquad \mathrm{R} 2=.20 ; \mathrm{F}=19.77 ; \mathrm{Sig}=.00\end{array}$} \\
\hline $\begin{array}{l}\text { Entrepreneurial Dimension } \\
\text { Entered }\end{array}$ & Beta & $\mathbf{t}$ & Significance \\
\hline Value Creation & 0.256 & 2.40 & 0.02 \\
\hline Customer Intensity & 0.228 & 2.14 & 0.03 \\
\hline \multicolumn{4}{|c|}{$\begin{array}{l}\text { Dependent Variable: Financial Success } \\
\qquad \mathrm{R} 2=.25 ; \mathrm{F}=30.99 ; \mathrm{Sig}=.00\end{array}$} \\
\hline $\begin{array}{c}\text { Entrepreneurial Dimension } \\
\text { Entered }\end{array}$ & Beta & $\mathbf{t}$ & Significance \\
\hline Value Creation & 0.310 & 4.20 & 0.00 \\
\hline Risk Taking & 0.303 & 4.10 & 0.00 \\
\hline \multicolumn{4}{|c|}{$\begin{array}{l}\text { Dependent Variable: Strong Company Success } \\
\qquad \mathrm{R} 2=.21 ; \mathrm{F}=13.38 ; \mathrm{Sig}=.00\end{array}$} \\
\hline $\begin{array}{l}\text { Entrepreneurial Dimension } \\
\text { Entered }\end{array}$ & Beta & $\mathbf{t}$ & Significance \\
\hline Value Creation & 0.342 & 3.77 & 0.00 \\
\hline Innovation-Oriented & 0.241 & 2.63 & 0.01 \\
\hline Resource Leveraging & 0.173 & 2.06 & 0.04 \\
\hline \multicolumn{4}{|c|}{$\begin{array}{l}\text { Dependent Variable: Excellence } \\
\text { R2 }=.66 ; \mathrm{F}=71.93 ; \mathrm{Sig}=.00\end{array}$} \\
\hline $\begin{array}{l}\text { Entrepreneurial Dimension } \\
\text { Entered }\end{array}$ & Beta & $\mathbf{t}$ & Significance \\
\hline Value Creation & 0.303 & 3.59 & 0.00 \\
\hline Proactiveness & 0.229 & 3.51 & 0.00 \\
\hline Innovation-Oriented & 0.214 & 3.39 & 0.00 \\
\hline Customer Intensity & 0.231 & 3.12 & 0.00 \\
\hline \multicolumn{4}{|c|}{$\begin{array}{l}\text { Dependent Variable: Personal Standard of Living } \\
\text { R2 }=.04 ; \mathrm{F}=8.18 ; \text { Sig }=.01\end{array}$} \\
\hline $\begin{array}{c}\text { Entrepreneurial Dimension } \\
\text { Entered }\end{array}$ & Beta & $\mathrm{t}$ & Significance \\
\hline Risk Taking & 0.223 & 2.86 & 0.01 \\
\hline
\end{tabular}


strong sustainable company. Other dimensions relate specifically to outcomes-risk taking related to financial success, customer intensity relating to customer success, and being innovative and leveraging resources to building a strong company. The use of entrepreneurial marketing in an SME can influence goal attainment on a personal level for the owner/operator and for the company. Entrepreneurial marketing also relates positively to creating a strong company as reflected by building a good employee base, creating a standalone business that can operate with or without the owner, and creating a culture of innovation and efficiency that can quickly respond to problems and support both customers and employees in a positive manner.

While all seven entrepreneurial marketing dimensions do not relate to all outcome variables, this research demonstrates that alone or in combination entrepreneurial marketing can affect positive outcomes.As it becomes more difficult to develop effective strategies, entrepreneurial marketing activities should continue to be investigated.

\section{Areas for Future Research}

Over the life cycle of the firm, there may be differences in how important entrepreneurial marketing is in strategy formation and how it is applied. By comparing SMEs with large corporations, it might be possible to determine which of the entrepreneurial marketing dimensions are actually more entrepreneurial and which are associated with general marketing tasks of all organizations. Also, looking more closely at the demographics, such as company age and industry category, may show how entrepreneurial marketing impacts performance outcomes.

Similarly with the importance of nonprofit organizations in our economy, it would be insightful to undertake a similar investigation among such organizations to see if they would have similar benefits to entrepreneurial activity. Variables such as leveraging and proactively might be key aspects of marketing activities in nonprofits as they often have critical resource constraints. Likewise, studying SMEs in key industry classifications or scope of business operations (from local to international) may reveal unique entrepreneurial marketing effects on outcomes. While this is exploratory research, the findings point to interesting relationships between entrepreneurial marketing and business and personal outcomes. Further research should utilize additional methodologies including in-depth interviews to identify unique aspects of entrepreneurial marketing that have particularly strong linkages to positive organization or entrepreneur success and raise new variables for further investigation.

Interestingly, there was no support for the link between entrepreneurial marketing and the opportunity focused component of new venture creation. Further research should attempt to isolate this proposed linkage and determine how the opportunity focused motive of entrepreneurs impacts entrepreneurial marketing. By studying only SMEs in operation for three years or less, it may be possible to isolate the impact of the opportunity-focused entrepreneurial marketing dimension. Again, this research is specifically focused on one aspect of companies that have sales under \$5 million annually and a limited number of businesses that are internationally-oriented in scope. Companies that are larger and have a more global focus may utilize entrepreneurial marketing in other ways and additional variables may emerge when such firms with a larger customer base are studied. By exploring companies with a more diverse demographic profile, additional dimensions may also emerge regarding the role of entrepreneurial marketing and outcomes in SMEs.

\section{References}

Armstrong, J.S. and Overton, T.S. (1977). Estimating Nonresponse Bias in Mail Surveys, Journal of Marketing Research, 16 (August), 396-492.

Barringer, B. R. and Ireland, R. D. (2010) Entrepreneurship: Successfully Launching New Ventures, 3rd Edition. New Jersey: Pearson Publishing.

Bateman, Thomas S. \& Crant, Michael J. (1993). The Proactive Component of Organizational Behavior:A Measure and Correlates, Journal of Organizational Behavior, 14 (2), 103-118.

Becherer, R. C., Halstead, D., \& Haynes, P. (2003). Marketing Orientation in SMEs: Effects on the Internal Environment, New England Journal of Entrepreneurship, spring, 6(1), 13-22.

Becherer, R. C., Finch, J. H., and Helms, M.M. (2005/2006). The Influences of Entrepreneurial Motivation and New Business Acquisition on Strategic Decision Making, Journal of Small Business Strategy. 16(2) 1-14.

Becherer, R. C., Haynes, P. J., and Helms, M.M. (2008). An Exploratory Investigation of Entrepreneurial Marketing in SMEs: The Influence of the Owner/Operator,Journal of Business and Entrepreneurship, 20(2), 44-63.

Becherer, R. C., Haynes, P. J., and Fletcher, L. P. (2006). Paths to Profitability in Owner-Operated Firms: The Role of Entrepreneurial Marketing, Journal of Business and Entrepreneurship. 18(1), 17-32 .

Becherer, R. C. \& Maurer, J. G. (1997). The Moderating Effect of Environmental Variables on the Entrepreneurial and Marketing Orientation of Entrepreneur-Led Firms, Entrepreneurship Theory and Practice, 22(1), 47-58. 
Beverland, M. \& Lockshin, L. S. (2004). Crafting a Competitive Advantage: Tempering Entrepreneurial Action with PositioningBased Values, Qualitative Market Research 7(3), 172-182.

Birley, S. (1982). Corporate Strategy and the Small Firm, Journal of General Management, 8(2), 82-86.

Birley, S. (1989). Female Entrepreneurs: Are They Really Different? Journal of Small Business Management 27(1), 32-37.

Carson, D. (2001). Marketing for Small to Medium Enterprises, in Baker, M. J. (Ed.) The Marketing Book, 4th edition. London: Butterworth-Heinemann Publishers, 621-639.

Carson, D. \& Gilmore,A. (2000). Marketing at the Interface: Not 'What' But 'How', Journal of Marketing Theory and Practice, $8(2), 1-7$.

Chaston, I. (1997). Small Firm Performance: Assessing the Interaction between Entrepreneurial Style and Organizational Structure, European Journal of Marketing, 31(11/12) 814-813.

Chaston, I. \& Mangles,T. (1999).A Teaching Model for Integrative the Alternative Philosophies of Transactional, Relationship and Entrepreneurial Marketing, American Marketing Association, winter, 33-39

Collinson, E., \& Shaw, E. (2001). Entrepreneurial Marketing-A Historical Perspective on Development and Practice, Management Decision, 39 (9), 761-766.

D'Ambroise, G. \& Muldowney, M. (1988). Management Theory for Small Business:Attempts and Requirements. Academy of Management Review, (13) 2, 226-240.

Deshpande, R., Farley, J. U. \& Webster, F. E. Jr. (1993). Corporate Culture, Customer Orientation and Innovativeness, Journal of Marketing, 57 (1), 23-37.

Dickson, P. R., \& Giglierano, J. J. (1986). Missing the Boat and Sinking the Boat:A Conceptual Model of Entrepreneurial Risk, Journal of Marketing, 50 (3), 58-71.

Dushnitsky, G. (2010). Entrepreneurial Optimism in the Market for Technological Inventions, Organization Science, 21(1), 150-167.

Forlani, D. \& Mullins, J.W. (2000). Perceived Risks and Choices in Entrepreneur's New Venture Decisions, Journal of Business Venturing, 15, 305-322.

Gompers, P., Kovner, A., Lemer, J., and Scharfstein, D. (2010). Performance Persistence in Entrepreneurship, Journal of Financial Economics, 96 (1), 18-29.

Gruber, M. (2004). Marketing in New Ventures: Theory and Empirical Evidence, Schmalenbach Business Review, 56, 164-199.

Hamel, G. \& Prahalad, C.K. (1994). Competing for the Future, Harvard Business Review, 72 (4), 122-129.

Hamel, G. (2000). Leading the Revolution. Cambridge, MA: Harvard University Press.

Han, J. K., Kim, N., and Srivastava, R. K. (1998). Market Orientation and Organizational Performance: Is Innovation a Missing Link? Journal of Marketing, 62 (October), 30-45.

Hills, G. E. (1987). Marketing and Entrepreneurship Research Issues: Scholarly Justification, Research at the Marketing/Entrepreneurship Interface, in Hills, G. E. (Ed.). Chicago: University of Illinois at Chicago, 3-15.

Hisrich, R. D. (1992). The Need for Marketing in Entrepreneurship, The Journal of Consumer Marketing, summer, 9(3), 43-47.

Jaworski, B. J., and Kohli, A. K. (1993). Market Orientation: Antecedents and Consequences, Journal of Marketing, 57 (3), 53-70.

Kirzner, I. M. (1997). Entrepreneurial Discovery and the Competitive Market Process: An Austrian Approach, Journal of Economic Literature, 35 (March), 60-85.

Li, Y.H., Huang, J.W., and Tsai, M.T. (2009). Entrepreneurial Orientation and Firm Performance: The Role of Knowledge Creation Process, Industrial Marketing Management, 38(4), 440-459.

Marcati,A., Guido, G., and Peluso,A. Mj. (2008). The Role of SME Entrepreneurs' Innovativeness and Personality in the Adoption of Innovations, Research Policy, 37(9), 1579-1601.

Martin, D. M. (2009). The Entrepreneurial Marketing Mix, Qualitative Market Research. 12(4), 391-493.

Matsuno, K., Mentzer, J.T. \& Özsomer,A. (2002). The Effects of Entrepreneurial Proclivity and Market Orientation on Business Performance, Journal of Marketing, 66 (3), 18-32. 
Miller, R. \& Floricel, S. (2004). Value Creation and Games of Innovation, Research Technology Management, 47 (6), 25-37.

Morris, M. H., Schindehutte, M. \& LaForge, R.W. (2002). Entrepreneurial Marketing:A Construct for Integrating Emerging Entrepreneurship and Marketing Perspectives, Journal of Marketing Theory and Practice, 10(4), 1-19.

Mullins, J.W. \& Forlani, D. (2005). Missing the Boat or Sinking the Boat:A Study of New Venture Decision Making,Journal of Business Venturing, 20, 47-69.

Narver, J. C., \& Slater, S. F. (1990). The Effect of a Market Orientation on Business Profitability,Journal of Marketing, 54 (4), 20-35.

Omura, G. S., Calantone, R. J. \& Schmidt, J. B. (1993). Entrepreneurism as a Market Satisfying Mechanism in a Free Market System, Hills and Mohan-Neill, (Eds). Scholarly Justification, Research at the Marketing/Entrepreneurship Interface, in Hills, G. E. (Ed.). Chicago: University of Illinois at Chicago, 161-171.

Palich, L. E., \& Bagby, D. R. (1995). Using Cognitive Theory to Explain Entrepreneurial Risk-Taking: Challenging Conventional Wisdom, Journal of Business Venturing, 10, 425-438.

Peters,T.J., and Waterman, R.H. (1982). In Search of Excellence: Lessons from America's Best Run Companies, New York, NY: Harper and Row.

Prahalad, C. K., \& Hamel, G. (1990). The Core Competence of the Corporation, Harvard Business Review, 68 (3), 79-92.

Read, S., Dew, N., Sarasvathy, S.D., Song, M. and Wilbank. R. (2009) Marketing Under Uncertainty: The Logic of an Effectual Approach, Journal of Marketing 73(3), 1-19.

Sarasvathy, S. D. (2001). Causation and effectuation: Toward a Theoretical Shift from Economic Inevitability to Entrepreneurial Contingency, Academy of Management Review, 26(2), 243-63.

Schindehutte, M. \& Morris, M. (2001). Understanding Strategic Adaptation in Small Firms, International Journal of Entrepreneurial Behavior and Research, 7 (3), 84-107.

Sharma, S., Netemeyer, R. G., and Mahajan, V. (1990). In Search of Excellence Revisited:An Empirical Evaluation of Peters and Waterman's Attributes of Excellence. In W. O. Bearden and A. Parasuraman (Ed.), Enhancing Knowledge Development in Marketing (Vol. 1, pp. 322-328).

Sheth, J., Sisodia, R. R. \& Sharma,A. (2000). The Antecedents and Consequences of Customer-Centric Marketing,Journal of the Academy of Marketing Science, 28 (1), 55-66.

Slater, S. F. \& Narver, J. C. (1995). Market Orientation and the Learning Organization, Journal of Marketing, 59 (3), 63-74.

Spence, M. and Essoussi, L. H. (2010). SME Brand Building and Management:An Exploratory Study, European Journal of Marketing, 44(7/8), 1037-1054.

Stokes, D. (2000). Putting Entrepreneurship into Marketing:The Process of Entrepreneurial Marketing,Journal of Research in Marketing \& Entrepreneurship, 2(1), 1-16.

Venkatraman, N. (1989). Strategic Orientation of Business Enterprises:Their Construct, Dimensionality and Measurement, Management Science, 35 (8), 942-962.

Wiklund, J. \& Shepherd, D. (2005). Entrepreneurial Orientation and Small Business Performance:A Configurational Approach, Journal of Business Venturing, 20 (1), 71-91.

York, J.G. and Venkataraman, S. (2010). The Entrepreneur-Environment Nexus: Uncertainty, Innovation, and Allocation, Journal of Business Venturing, 25(5), 449-458 


\section{About the Authors}

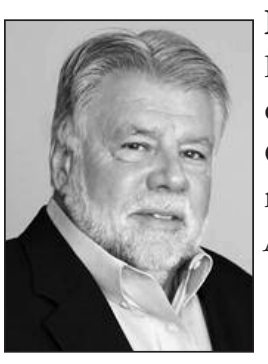

RICHARD C. BECHERER (richard-becherer@utc.edu) holds the Clarence E. Harris Chair of Excellence in Business and Entrepreneurship at the University of Tennessee at Chattanooga. He has had extensive experience both as an academic and as an entrepreneur. He cofounded one of the first for-profit Health Maintenance Organizations in the United States, which became a public company. He has been published in numerous journals, including Entrepreneurship Theory and Practice, Journal of Small Business Management, Journal of Marketing, and Decision Sciences.

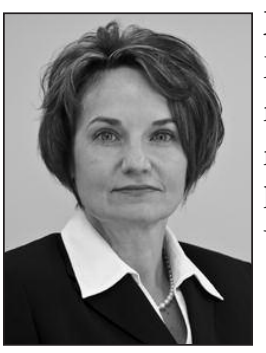

Marilyn M. Helms (mhelms@daltonstate.edu) holds the Sesquicentennial Chair and is a Professor of Management at Dalton State College. She works closely with the area community on research projects, seminars, and training programs. She teaches strategic management and entrepreneurship. She is the author of numerous business articles and writes a monthly column for the Dalton (GA) Daily Citizen newspaper. She holds a doctorate degree from the University of Memphis (Tennessee) and was a Fulbright scholar at the University of Coimbra, Portugal.

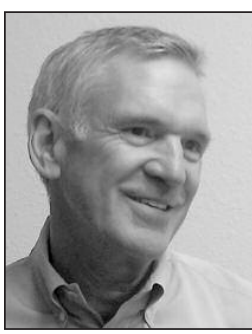

JOHN P. McDonald (john.mcdonald@grandcanyon.edu) is EMBA program director at Walden University. He teaches in the marketing, strategy, and entrepreneurial areas. Dr. McDonald has an extensive career in industry, primarily in leading marketing research organizations working with a wide range of businesses from startups to Fortune 100 firms. He is also the author of several articles and papers in the marketing discipline. 